\title{
Podpora in pomoč osebam z anoreksijo
}

\section{Pozitivni in negativni vidiki spletnih pro-ana strani}

\begin{abstract}
Ljudje, ki zaradistisk ob motnjah hranjenja potrebujejo pomoč in podporo, se pogosto prej kot k socialnim delavkamobračajok virtualnimskupnostim, sajso hitrejedostopne. Vsocialnem deluso t. i. pro-anaspletnestranislaboznane. Včlanku so prikazane do zdajznane ugotovitveo koristnih in škodljivih vplivih pro-ana strani in o pomenu, ki ga lahko imajo za socialno delo. Predstavljena je kvalitativna raziskava na neslučajnostnem priložnostnem vzorcu 20 ljudi, ki obiskujejo pro-ana spletne strani. Poglavitna vloga pro-ana spletnih strani je, da uporabnicam ponujajo možnost anonimnega pridobivanja informacij, vodenja in čustvene podpore. Na eni strani jim pomenijo občutekvključenostivskupnost, a imajo lahkotudinegativneučinke, sajnekatere pro-anaspletne strani spodbujajo k motnjam hranjenja. Zato je pomembno, da kot socialne delavke razumemo, kajuporabnice naspletnih straneh pritegne in katere svoje potrebe tam lažje in hitrejezadovoljijo, da bomo ob srečanju z njimi znali ponuditi ustrezno podporo in pomoč.
\end{abstract}

Ključne besede: motnje hranjenja, internet, spletne podporne skupine, socialno delo.

Gaja Černe je je diplomirana socialna delavka, študentka magistrskega študija na Fakulteti za socialno delo. Kontakt: gaja.cerne@gmail.com.

Doc. dr. Liljana Rihter je zaposlena kot visokošolska učiteljica in raziskovalka na Fakulteti za socialno delo. Kontakt: liljana.rihter@fsd.uni-lj.si.

\section{Support and help for people with anorexia - Positive and negative aspects of pro-ana websites}

Individuals suffering from eating disorders often turn to virtual communities for help and support, as these are often more accessible than social workers. In social work the so-called pro-ana websites are poorly known. In the paper, findings on the beneficial and harmful effects of pro-ana websites are presented, together with their implications for social work. A qualitative online survey on a non-random convenience sample of 20 pro-ana website users is described. The main function of pro-ana websites is to provide users with the opportunity to anonymously obtain information, receive guidance and emotional support. However, the sense of community and inclusion can also have negative effects, as some pro-ana websites encourage eating disorders. It is, therefore, important that we, as social workers, understand what attracts users to these websites and identify which user's needs are met quicker and easilier through them. This way we can offer appropriate help and support when we meet the users.

Keywords: eating disorders, internet, website support groups, social work.

Gaja Černe is a graduate social worker and a Master student at the Faculty of Social Work, University of Ljubljana. Contact: gaja.cerne@gmail.com.

Liljana Rihter, PhD, is an assistant professor employed as a university teacher and researcher at the Faculty of Social Work, University of Ljubljana. Contact: liljana.rihter@fsd.uni-lj.si.

\section{Uvod}

Socialne delavke imamo ključno vlogo pri podpori in pomoči osebam z motnjami hranjenja. ${ }^{1}$ Pomagamo jim pri okrevanju in ponovni vključitvi v šolo, delo in življenje v skupnosti. Raziskujemo, kako posameznik deluje v svojem okolju, v svoji skupnosti, v svoji socialni mreži in kako to vpliva na bolezen. Vse več oseb z motnjami hranjenja se po pomoč raje zateče na splet, kot da bi

1 Članek je nastal na podlagi diplomskega dela Černe (2020), mentorica je vodilna avtorica tega članka.. 
poiskali profesionalno pomoč (Van Pelt, 2009). Z globalizacijo ter razvojem interneta in socialnih omrežij so vsebine o motnjah hranjenja hitro dostopne.

Internet na eni strani ponuja možnost anonimnega pridobivanja informacij, vodenja in čustvene podpore, so pa na drugi strani socialna omrežja olajšala širjenje sporočil, ki spodbujajo k motnjam hranjenja. V kontekstu pomoči pri okrevanju v povezavi z motnjami hranjenja se je pojavil nov izziv. V zadnjih letih se je povečalo število spletnih strani in blogov, tako imenovanih pro-ana strani (pro-ana je okrajšava za pro-anoreksija).

Bond (2012, str. 39) trdi, da so strani pro-ana skupnost, ki motnje hranjenja obravnavajo kot življenjski slog, ne pa kot motnje, ki jih je treba zdraviti. Ekstremnih prehranjevalnih navad ne vidijo kot problematičnih. Rich (2006, str. 285) meni, da objave na takih straneh prikazujejo željo po ohranitvi motnje hranjenja pa tudi, kako postati »boljši anoreksik«. Vsebine teh strani so najpogosteje fotografije izrazito suhih deklet, tako imenovanih thinspiration (skovanka iz angleških besed thin, suh, in inspiration, navdih, se pravi »idealne trlice«), besedila z informacijami o tehnikah in trikih za doseganje ekstremne izgube teže, motivacijska pisma, različni videoposnetki in citati, ki spodbujajo k hujšanju. Ponujajo informacije o motnjah hranjenja in tehnikah hujšanja, vendar so ta »dejstva « prikazana na pogosto izkrivljen način, brez zagotovila za uspeh ali verodostojnosti (Borzekowski, Schenk, Wilson in Peebles, 2010, str. 1532). Leta 2006 je raziskava na Medicinski šoli Stanford pokazala, da je 35,5\% oseb z motnjo hranjenja obiskalo strani pro-ana. Od tega se jih je $96 \%$ naučilo novih načinov hujšanja (Conger, 2006).

Strife and Rickard (2011, str. 213-217) sta izvedla raziskavo, s katero sta ugotovila, da obstajata dve vrsti uporabnic ${ }^{2}$ strani pro-ana. Tiste, ki anoreksijo vidijo kot način življenja, in tiste, ki anoreksijo vidijo kot bolezen. Čeprav se nekatere uporabnice zavedajo, da je anoreksija bolezen, ne želijo ozdraveti oziroma se še niso odločile za zdravljenje. Uporabnice, ki anoreksijo vidijo kot način življenja, verjamejo, da so se za anoreksijo odločile same (Happel Krautbauer, 2016, str. 11).

Raziskava Borzekowske, Schenk, Wilson in Peebles (2010, str. 1531) kaže: čeprav vlada prepričanje, da pro-ana strani anoreksijo vidijo kot način življenja in k njej spodbujajo, je takih strani manj kot $20 \%$. Pri večini strani ni šlo za spodbujanje k motnjam hranjenja, čeprav so vsebovale iste elemente (fotografije, motivacijske misli, osebne izpovedi) kot pro-ana strani, ki spodbujajo k anoreksiji, saj so prve uporabljale objave za lastne namene, za lažje spoprijemanje z boleznijo. Vsebovale so še različna opozorila, naj do objav ne dostopajo osebe s hudimi težavami z motnjami hranjenja.

Točnega podatka o tem, koliko pro-ana spletnih strani obstaja, ni, saj so zelo dinamične in včasih kratkotrajne (npr. izbrisane zaradi neprimerne vsebine), poleg tega pa se vsak dan pojavljajo nove strani. Abbate, Gramaglia, Pierò in Fassino (2006, str. 68) so leta 2006 ocenili, da na svetu obstaja vsaj 300.000 pro-ana spletnih strani. Gotovo se je v zadnjih štirinajstih letih ta številka še povečala.

2 Izraz uporabnica je v članku uporabljen za oba spola, ker je žensk z anoreksijo precej več kot moških. 
V nadaljevanju bova najprej prikazali koristne in škodljive vplive pro-ana strani ter podrobneje predstavili povezavo med omenjenimi stranmi in socialnim delom. Nato pa bova predstavili lastno raziskavo o poglavitnih vlogah pro-ana spletnih strani, o razlogih za dostopanje do njih in učinkih oz. koristih ali slabostih, ki jih ima lahko obiskovanje takih strani za posameznice. Raziskavo sva izvedli z namenom, da bi bolje spoznali pro-ana skupnosti in da bi lahko morebitne pozitivne vloge pro-ana spletnih strani uporabili za krepitev moči obolelih za anoreksijo na spletu in v resničnem življenju.

\section{Škodljivi vplivi in koristi pro-ana strani}

Najnevarnejši vidik strani pro-ana je spodbujanje k anoreksiji. Uporabnice motivirajo k stradanju ali drugim škodljivim vedenjem (npr. k bruhanju). Ta vedenja s spodbujanjem normalizirajo, saj uporabnica čuti, da so sprejemljiva, upravičena in včasih celo zaželena (Schroeder, 2010, str. 17). Druga skrb je potencial, da bi pro-ana skupnosti lahko poveličevale ali romantizirale motnje hranjenja, na primer s prikazom vedenj kot »tragično lepih« (Bine, 2013).

Hujšanje in izgubo kilogramov prikazujejo kot uspeh. Lakoto predstavljajo kot dobro, hranjenje kot sramotno (Happel Krautbauer, 2016, str. 44). Hranjenje reprezentirajo, kot da povzroča nezaželene telesne in družbene posledice in pomanjkanje samostojnosti, lakota pa je prikazana kot zaželena in pokazatelj doseganja ciljev. Objave, ki prikazujejo lakoto kot zaželeno, lahko uporabnice motivirajo, da še naprej stradajo, kljub telesnemu nelagodju, ki ga lakota spremlja (Happel Krautbauer, 2016, str. 45).

Pro-ana strani z različnimi objavami, besedili in fotografijami manipulirajo z uporabnicam, ovirajo njihovo željo po okrevanju in jih motivirajo za bolezen. Med uporabnicami poteka tekmovanje, katera bo bolj suha (Borzekowski, Schenk, Wilson in Peebles, 2010, str. 1526).

Zakaj se kljub negativni publiciteti pro-ana strani in naporom za izbris te še naprej pojavljajo? Zakaj se uporabnice z motnjami hranjenja kljub omenjenim negativnim ali škodljivim vplivom obračajo nanje?

Ključna sestavina spoprijemanja z motnjo (kakršna je tudi anoreksija) je udeleževanje terapevtskega svetovanja (Tozzi, Sullivan, Fear, McKenzie in Bulik, 2003, str. 149). Ta srečanja večinoma potekajo v živo in se jih morajo uporabnice fizično udeležiti. To lahko povzroči različne težave, kot so strah pred nesprejetjem, strah, da svetovanje osebi ne pomaga, obvezna navzočnost (McCormack in Coulson, 2009, str. 9). Poleg tega motnje pogosto dojemamo kot precej zasebne in skrivne. To še posebej velja za motnje hranjenja, saj so v družbi negativno stigmatizirane (Eichhorn, 2008, str. 67).

Negativna stigmatizacija lahko povzroči, da ljudje, ki trpijo zaradi težav z duševnim zdravjem ali drugih ovir in motenj, čutijo sram ali strah, da jih drugi ne bodo jemali resno. Zato bi bil morda prevelik korak, da bi poiskali podporo in nasvet $\mathrm{v}$ neposredni bližini. Namesto tega so začele uporabnice prednostno uporabljati internet in zlasti družbena omrežja, saj lahko zagotavljajo podobne prakse pa tudi več informacij o zdravju in boleznih (Patel, 
Chang, Greysen in Chopra, 2015, str. 1335). Internet ponuja javni prostor, kjer so uporabnice tiste, ki skrbijo za vsebino in način uporabe.

Tierney (2006, str. 181-190) meni, da se posameznice z motnjami hranjenja pogosto umaknejo iz odnosov in situacij, kjer so zaradi svoje motnje in z njo povezanega vedenja lahko izpostavljene. Pro-ana strani jim zagotavljajo varno mesto, kjer se te posameznice lahko poistovetijo $\mathrm{z}$ drugimi in se izognejo izolaciji, ki je po navadi povezana $\mathrm{z}$ njihovo motnjo.

Pomembna korist pro-ana spletnih strani je lahko pisanje blogov. Schmidt, Bone, Hems, Lessem in Treasure (2002, str. 299-315) trdijo, da je pisanje koristno za bolnice z motnjami hranjenja. Opozarjajo na raziskave, ki kažejo, da ima pisanje največ koristi za tiste, ki imajo manj možnosti, da se zaupajo drugim, ali pripadajo stigmatizirani družbeni skupini (Richards, Beal, Seagal in Pennebaker, 2000, str. 156-160). Študija Ko in Pu (2011), ki jo povzemajo Pettersen, Rørvik in Wanvik (2011, str. 19), je pokazala, da pisanje o sebi lahko izboljša blogerkine socialne mreže, spodbuja samorazumevanje, sproži pozitivne povratne informacije in poveča odpornost.

Ti rezultati se skladajo z ugotovitvami Miure in Yamashite (2007, str. 1452-1471), ki prav tako trdita, da lahko pisanje na blogih poveča sposobnost obdelave informacij in poveča psihično zadovoljstvo. Bronstein (2013, str. 161-181) navaja ugotovitve raziskave med blogerkami, ki kažejo, da so ustvarile virtualno navzočnost v svojih blogih. Dojemajo jih kot varen prostor, bile so zadovoljne, ko so na svojem blogu objavile nov zapis in prejele komentarje. Svoje bloge so opisale kot del sebe, kot komunikacijsko orodje, kot orodje za pisanje in svoj najljubši hobi (Bronstein, 2013, str. 161-181).

Ko in $\mathrm{Pu}$ (2011) opisujeta socialno podporo kot posebej pomemben dejavnik pri večanju odpornosti. Ker samorazkritje na blogih blogerkam prinese socialne koristi, lahko to pomaga pri oblikovanju obrambnih mehanizmov in spodbujanju odpornosti (gl. Pettersen, Rørvik in Wanvik, 2011, str. 19). Pisanje ima v določenih okoliščinah torej terapevtski učinek. Možnost tega pristopa pri uporabnicah z motnjami hranjenja je zelo uporabna še posebej zato, ker imajo navadno večje težave $\mathrm{z}$ odpiranjem in pogovorom o svojem stanju kot druge skupine uporabnic (Pettersen, Rørvik in Wanvik, 2011, str. 19-20).

Pettersen, Rørvik in Wanvik (2011, str. 30) menijo, da sta poglavitni razlog in hkrati največja korist, da se osebe z motnjami hranjenja obračajo na take strani, občutek pripadnosti skupnosti. V tej skupnosti vzpostavljajo nova prijateljstva in poznanstva, to pa jim vzbuja občutek pripadnosti. Uporabnice med seboj spletejo tesne prijateljske vezi, čeprav se nikoli niso videle v živo. Občutek imajo, da jih druge članice razumejo, spoštujejo in jih ne obsojajo. Zaradi podpore drugih z različnimi komentarji, všečki, zasebnimi sporočili so lahko uporabnice bolj sproščene, saj ponotranjijo sprejetje in se počutijo manj osramočene. Nekatere to povezujejo z občutki veljave, dragocenosti in prepoznavnosti. Druga drugo motivirajo in si dajejo različne nasvete, ko napišejo kaj osebnega in občutljivega. Zdi se, da uporabnice potrebujejo svoje bralke za izpovedovanje, govorjenje o svojih težavah in spoprijemanje z njimi. To bi lahko razumeli tudi kot obrambni mehanizem (Pettersen, Rørvik in Wanvik, 2011, str. 38). 
Mulveen in Hepworth (2006, str. 283-296) ugotavljata, da uporabnice pogosto poudarjajo pro-ana skupnosti kot nekaj, kar jim pomeni vir socialne in čustvene podpore. Spletne strani imajo za varen prostor, kjer lahko govorijo o svojih motnjah hranjenja. Podporo dobijo tako pri spodbujanju motenj hranjenja (npr. ko druge uporabnice podprejo ekstremno dieto kot metodo hujšanja) kot pri okrevanju (npr. ko so uporabnice poročale, da imajo nevarno majhno težo ali so prevzele še bolj skrajne vzorce neurejenega prehranjevanja, so jih drugi spodbujali k okrevanju). Uporabnice tudi poročajo, da na pro-ana strani gledajo kot na kraj, kjer jim ni treba skrivati stradanja in drugih nezdravih navad zaradi strahu pred obsojanjem ali prisilo k zdravljenju, če se še niso odrekle svojemu življenjskemu slogu (Happel Krautbauer, 2016, str. 14-15).

Winzelberg (1997, str. 395) predlaga, naj na spletne podporne skupine gledamo kot na vmesni korak med posameznikovim spopadanjem z motnjo in strokovno pomočjo. Ugotovil je, da se podpora med članicami skupnosti pogosto kaže s samorazkritjem in ima pomembno vlogo pri spoprijemanju $\mathrm{s}$ povečanjem telesne teže med okrevanjem ali z zunanjimi pritiski družin, prijateljic in družbe uporabnic. Samorazkritje na spletnih forumih je lažje in pogostejše, saj je po svoji naravi »brez telesa«, zato so obsodbe, povezane z videzom, bolj ali manj odpravljene (Hekman, 2016, str. 12).

\section{Pro-ana skupnosti in socialno delo}

Ključno je, da socialne delavke in delavci poznamo veliko spletnih virov, ki so zlahka dostopni uporabnicam in jih pogosto uporabljajo osebe z motnjami hranjenja. Glede na to, da sta za motnje hranjenja značilna sram in zanikanje, je zelo verjetno, da bodo osebe z motnjami hranjenja že naletele na pro-ana strani in forume, preden začnejo profesionalno zdravljenje. Da bi jim lahko ustrezno pomagali, moramo najprej razumeti, kaj pro-ana strani so, kaj so njihove vloge in kaj so informacije, ki jih osebe z motnjami hranjenja prejemajo na teh straneh (Reali, 2015, str. 3).

Socialne delavke in delavci lahko ugotovitve uporabimo za bolj odkrite pogovore z osebami z motnjami hranjenja. Če uporabnice razkrijejo, da so uporabljale pro-ana strani, ima socialna delavka že predstavo o tem, kakšne nasvete so si uporabnice ogledale oziroma prejele, in lažje vodi uporabnice $\mathrm{k}$ nadaljnjemu pogovoru o netočnih informacijah, ki so jih morda prejele, in $\mathrm{k}$ učinkovitejšemu okrevanju. Socialna delavka se z uporabnico lahko pogovori o razlogih za obiskovanje pro-ana strani in jo usmeri k varnejšim, boljšim alternativam, npr. k skupini za samopomoč, če je uporabnica izrazila, da se je v svoji bolezni počutila osamljeno, pro-ana strani pa so ji dale občutek pripadnosti skupini.

Tudi Pettersen, Rørvik in Wanvik (2011, str. 76) menijo, da moramo biti strokovni delavci ozaveščeni o teh spletnih straneh. Večina mladih uporabnic z motnjami hranjenja uporablja internet in velika verjetnost je, da bodo naletele na pro-ana strani. Svetovanje izboljšamo tako, da se uporabnica in socialna delavka skupaj pogovorita o vplivu, ki ga imajo te strani na uporabničino zdravljenje in željo po okrevanju. 
De Shazer (1985) je ugotovil, da oseba v psihoterapiji v večini primerov dobi več tistega, o čemer govori, dobrega ali slabega, zato se je bolje pogovarjati o rešitvi problema kot pa o problemu samem. To lahko navežemo na primer uporabe pro-ana strani. Uporabnica teh strani bo namreč (ostala) osredotočena na problem (tj. motnjo hranjenja) in ne na rešitev (tj. zdravljenje).

Zgodovina je pokazala, da pro-ana strani ni mogoče popolnoma odstraniti, zato bi moral biti cilj izkoristiti pozitivne in zmanjšati negativne vidike teh spletnih mest. Pomembno je poglobiti znanje o pro-ana skupnosti, poleg tega pa članicam te skupnosti, ki so prišle na terapijo, pomagati, da bi našle kako drugo podporo. Več kot terapevti vedo o tej tematiki, bolj lahko pomagajo svojim uporabnicam pri spoprijemanju s skušnjavo, da se vrnejo v pro-ana skupnost (Boniel-Nissim in Latzer, 2016, str. 19).

\section{Problem in metodologija raziskave}

Zaposlene na področju pomoči in podpore osebam z motnjami hranjenja glede na izkušnje iz najine prakse pro-ana spletnih strani sploh ne poznajo. Praktične izkušnje prve avtorice pa so pokazale, da je že samo zavedanje o obstoju pro-ana strani ob individualnem svetovalnem delu $\mathrm{z}$ uporabnicami zelo pomagalo pri njihovem okrevanju. Zato sva želeli z raziskavo poglobljeno raziskati določen obseg pro-ana strani na socialnem omrežju Tumblr. Zanimalo naju je, kaj so poglavitne naloge takih strani, zakaj jih ljudje ustvarjajo oziroma dostopajo do njih, ali si uporabnice teh strani sploh želijo okrevati ter ali imajo te strani lahko tudi pozitivne učinke (npr. občutek pripadnosti, novi prijatelji in prijateljice, pomoč pri okrevanju). Namen raziskave je bil bolje spoznati pro-ana skupnost in morebitne pozitivne vplive pro-ana spletnih strani uporabiti za izboljšanje postopkov zdravljenja in okrevanja obolelih za anoreksijo na spletu in v resničnem življenju.

Raziskava, ki sva jo izvedli, je bila kvalitativna in empirična (Mesec, 1997, str. 84-85). Za merski instrument sva izdelali strukturiran anketni vprašalnik, ki je obsegal 19 vprašanj odprtega tipa. Populacija so bile osebe, ki imajo težave zaradi anoreksije in ustvarjen pro-ana profil na socialnem omrežju Tumblr. Iz populacije sva izbrali 20 oseb tako, da sva v iskalnik na socialnem omrežju Tumblr vtipkali oznako "proana« in videli, kdo so uporabnice, ki so nazadnje objavile nekaj pod to oznako. Vzorec je tako neslučajnostni in priložnostni.

Anketirank nisva poznali od prej. Metoda zbiranja podatkov je anketa. Anketiranje sva izvedli med 30. januarjem 2020 in 1. februarjem 2020 prek klepetalnika na socialnem omrežju Tumblr. To pomeni, da anketirank nisva videli v živo, temveč sva bili z njimi v stiku le prek sporočil. Pošiljali sva jim posamično vprašanje, počakali na njihov odgovor in nato nadaljevali z naslednjimi vprašanji. Anketiranje je potekalo v angleščini. Dobljene podatke sva analizirali po postopku kvalitativne analize z odprtim, osnim in odnosnim kodiranjem, ki nama je omogočilo izpostaviti povezave med značilnostmi uporabnic, razloge za uporabo spletnih strani in vplive teh strani. 


\section{Rezultati}

Skoraj vse uporabnice, s katerimi sva se pogovarjali, so menile, da je anoreksija bolezen. Se pa tiste, ki menijo, da je anoreksija bolezen, na spletnih straneh ne povezujejo s skupino uporabnic, ki anoreksijo vidijo kot življenjski slog (teh je bilo v najini raziskavi manj). Nekatere uporabnice, ki anoreksijo vidijo kot način življenja, so opisale, da je anoreksija zanje metafora. »Ano« vidijo kot osebo, boginjo, prijateljico, ki jih motivira, navdihuje, jim daje moč.

Kot poglavitni nalogi pro-ana strani sta se pokazali spodbujanje motnje hranjenja in občutek pripadnosti skupnosti. Spodbujanje motnje hranjenja se kaže v svetovanju o skrivanju motnje, v spodbujanju k nezdravemu načinu življenja, spodbujanju občutkov krivde, ko oseba poje več. Uporabnicam pomenijo pro-ana strani tudi občutek skupnosti, saj omenjajo pridobivanje novih prijateljic, podporo in občutek, da niso same. Veliko oseb z motnjami hranjenja ima namreč občutek, da so v tem same, da v resničnem življenju nimajo nikogar, ki bi jim stal ob strani, in se zato zatekajo na splet, kjer najdejo skupnost ljudi z enakimi težavami. Pro-ana strani imajo torej tudi vlogo zdravljenja; so način spoprijemanja z boleznijo, strategija obvladovanja posameznice in lahko pripomorejo $\mathrm{k}$ boljšemu duševnemu zdravstvenemu stanju.

Vsekakor je to nezdrav način spopadanja, toda ko se ti zdi, da je to edina strategija obvladovanja, se je trdno držiš. (S12)

Uporabnic ne silijo ne v bolezen in ne v zdravljenje.

... da poskušajo zvabiti dekleta v motnjo, večinoma tega ne počnejo, ne bodo pa silile deklet, da se grejo zdravit, če niso pripravljene. (R9)

Pro-ana strani imajo tudi izpovedovalno funkcijo. Po Ciottiju (2016) je pisanje povezano z izboljšanjem počutja in zmanjšanjem stresa pri tistih, ki to počnejo redno. Pisanje o negativnih mislih, svojih problemih ipd. prinaša čustveno sproščanje, z njim lajšamo čustveno napetost, je katarzično. Izboljšuje telesno in duševno zdravje, zmanjšuje tesnobo in depresijo. Pisanje najbolj koristi tistim, ki imajo manj možnosti, da se zaupajo drugim, ali pa pripadajo stigmatiziranim družbenim skupinam (Richards, Beal, Seagal in Pennebaker, 2000, str. 156-160).

Skårderud (2003, str. 82) opisuje, da je občutek sramu pogosto povezan s tišino in zadrževanjem, da bi svoja čustva in misli izrazili z besedami. Strani imajo tudi položaj moči, ki se kaže v posredovanju nasvetov. Strife in Rickard (2011, str. 215) opozarjata na razlike v rabi jezika. Tiste uporabnice, ki so izrazile stališče, da je anoreksija življenjski slog, uporabljajo jezik, ki poudarja nadzor in moč ter kaže na to, da se zmorejo odpovedati hrani, da so resnično močne in imajo popoln nadzor nad svojim življenjem. Po zaslugi posredovanja nasvetov drugim se počutijo večvredne, močnejše. Z raziskavo sva ugotovili tudi, da so pro-ana strani tudi medij za spolne perverzneže, ki z lahkoto dostopajo do slik in uživajo ob gledanju pogosto pomanjkljivo oblečenih deklet z anoreksijo, saj te na spletu redno objavljajo svoje fotografije in se ne zavedajo, kdo vse te fotografije vidi. 
Razlogi za ustvarjanje pro-ana vsebin oziroma dostopanje do njih so različni in odvisni od posameznice. V najini raziskavi so anketiranke najpogosteje omenjale občutek skupnosti, ki jim ga pro-ana strani zagotavljajo. Gre za občutek pripadnosti, pogosto je vzpostavljanje novih prijateljstev in poznanstev. Uporabnice med seboj spletejo tesne prijateljske vezi, čeprav se še nikoli niso videle v živo. Imajo občutek, da jih druge članice razumejo, spoštujejo in jih ne obsojajo.

O svoji motnji hranjenja ne morem govoriti s svojimi starši ali prijatelji, zato je zelo lepo imeti skupnost, ki razume. (S8)

Drugi najpogostejši razlog je hujšanje. Pro-ana strani zagotavljajo pomoč in motivacijo za izgubo teže, provocirajo uporabnice, spodbujajo, informirajo o varni hrani, objavljajo načrte telovadbe, utrjujejo željo po spremembi videza. Objave, ki prikazujejo lakoto kot sramotno, lahko uporabnice motivirajo, naj še naprej omejujejo vnos hrane oziroma naj stradajo kljub telesnemu nelagodju, ki ga lakota spremlja (Happel Krautbauer, 2016, str. 45). Za nekatere je razlog uporabe pro-ana strani razumevanje drugih uporabnic in možnost izpovedovanja, drugim pro-ana strani pomenijo varen prostor.

In ko sem našla te strani, sem jih doživela kot nekakšno »varno mesto«, kjer sem se lahko pogovarjala z ljudmi, ki so šli skozi iste stvari kot jaz, in tako sem lahko z njimi delila svoje misli, ne da bi obremenjevala koga od moje družine ali prijateljev iz resničnega življenja. (P5)

Nekatere si zavestno prizadevajo za poslabšanje svojega zdravstvenega stanja: prepričati se hočejo, da imajo res motnjo, ali hočejo s pomočjo uporabe strani razviti anoreksijo.

In nekako si želim priti do tega stanja v resničnem življenju, zato da me bodo drugi jemali resno in mi bodo verjeli. (D7)

Eden izmed razlogov je tudi stereotipiziranje motenj hranjenja oziroma spregledanost teh motenj zaradi stereotipov. Stereotipna predstava osebe, ki trpi za motnjo hranjenja, je suha, mlajša ženska, vendar to ni nujno res. Za motnjo hranjenja lahko zboli vsak, ne glede na starost, raso oziroma etnično pripadnost, spol ali telesno težo. Ker nekatere uporabnice na pogled ne ustrezajo tej predstavi, jih družinski člani, prijatelji in strokovnjaki ne jemljejo resno in se uporabnice tudi same začnejo počutiti, kot da same sebi lažejo, da imajo motnjo hranjenja. Pro-ana skupnosti jim zagotavlja prostor, kjer jih druge uporabnice vzamejo resno in verjamejo $\mathrm{v}$ njihovo bolezen.

Raziskovali sva tudi vplive pro-ana strani na misli in občutke, vedenje, odnose s prijateljicami in družino ter na okrevanje oseb s težavami zaradi anoreksije. Ugotovili sva, da pro-ana strani pri uporabnicah vzbujajo pozitivne občutke (npr. vznemirjenost), negativne občutke (npr. jezo) ali mešana čustva (npr. ljubezen in sovraštvo).

Sovražim vse glede teh spletnih strani, pa vendar ... na nek način jih imam rada. (U28)

Strani večinoma na misli in občutke vplivajo negativno, saj pripomorejo k slabšemu duševnemu zdravju, slabši samopodobi, manjši samozavesti, pre- 
pričujejo uporabnice, da so osamljene, da se morajo počutiti osamljene, jih prepričujejo, da imajo anoreksijo ... Pozitivno pa vplivajo na uporabnice tako, da jim pomagajo pomiriti se ob prenajedanju, spodbujajo in opominjajo jih, da so zdaj zdrave, in jim pomagajo odgnati negativne misli. Zaradi podpore drugih je lahko uporabnica bolj sproščena, saj ponotranji sprejemanje motnje in se počuti manj osramočeno. Nekatere uporabnice so zaradi pro-ana objav razvile glas v glavi, ki jim govori, kaj naj počnejo oziroma česa naj ne počnejo. Pro-ana strani vplivajo tudi na povečano tekmovalnost glede hujšanja in motnje hranjenja, vplivajo pa lahko tudi na to, da uporabnice popačeno vidijo telesa. Telesa, ki so jih v preteklosti videle kot suha, zdaj vidijo kot debela.

Več kot polovica anketirank v raziskavi meni, da je vpliv pro-ana strani na vedenje negativen. Tudi Schroeder (2010, str. 17) ugotavlja, da pro-ana strani uporabnice motivirajo k nadaljnjemu stradanju ali drugim škodljivim vedenjem, npr. samopoškodovanju. Številne uporabnice so začele uporabljati metode za izgubo telesne teže (npr. stradanje, omejevanje vnosa hrane). Kljub vsemu pa je zelo verjetno, da bi se tako vedle tudi, če pro-ana strani ne bi uporabljale.

Vseeno bi stradala in se omejevala, vendar pa mi strani dajo občutek, da je to $v$ redu, naj se ne počutim osramočeno zaradi svojih prehranjevalnih navad, čeprav vem, da niso zdrave. (R29)

Strani s spodbujanjem k tem vedenjem normalizirajo ta vedenja tako, da uporabnica čuti, da so sprejemljiva, upravičena in včasih celo zaželena. Pozitivna plat teh strani je, da vplivajo na to, da uporabnice jedo bolj zdravo, in jim predstavljajo veliko tehnik zmanjševanja škode, ki jih uporabnice nato upoštevajo (npr. jemanje dodatnih elektrolitov). Pro-ana strani lahko vplivajo tudi na to, da uporabnica fizično zboli ali pa razvije motnjo hranjenja, če je pred tem ni imela.

Pro-ana strani na spremembo odnosov večinoma ne vplivajo, nanje vpliva motnja hranjenja sama. Zaradi utrujenosti in žalosti uporabnic so odnosi slabši in bolj zapleteni, saj pogosto izbruhnejo prepiri. Uporabnico je strah, da jo bodo drugi zapustili, to pa velikokrat povzroči oddaljitev in občutek osamljenosti. Ker jim družinski člani in prijateljice včasih ne verjamejo oziroma ne vidijo, da so bolne, si uporabnice želijo bolezen utemeljiti in jim dokazati, da so res bolne.

To je del razloga, zakaj si želim postati res »slaba«, da ji dokažem, da sem res bolna. (E22).

Pro-ana strani vplivajo na to, da se uporabnice zapirajo vase, se izolirajo, izogibajo se družinskim večerjam, druženju s prijateljicami in družino. Ker jim je težko govoriti z njimi, se jim raje izogibajo. Pogosto nimajo veliko prijateljic v resničnem življenju in se raje pogovarjajo s spletnimi. Motnjo navadno pred drugimi skrivajo.

Večina anketiranih uporabnic je menila, da imajo pro-ana strani na okrevanje slab vpliv in več kot polovica uporabnic si sploh ne želi okrevati. Pro-ana strani s provokativnimi vsebinami zmanjšujejo željo po okrevanju oziroma otežujejo okrevanje in povečujejo željo biti suh. Nekatere se na skupnost pre- 
več navežejo, saj imajo tam prijateljice, podporo, in zato nočejo oditi. Pro-ana vsebine pri tistih, ki so že okrevale, vzbujajo željo ponovno zboleti.

Ko sem si opomogla, sem morala izbrisati svoje račune in jih odstraniti. V trenutku, ko stvari postanejo ponovno težke? Takoj nazaj k njim in ponovno si na začetku. (T43)

Po drugi strani pa pro-ana strani uporabnic ne silijo, ampak spodbujajo k zdravljenju, in ta pristop se uporabnicam zdi ključen za okrevanje. Pri terapiji jih npr. moti prav to, da jih silijo jesti. Anoreksija je ozdravljiva, vendar je zelo pomembno, da se posameznica sama odloči za zdravljenje in da je za okrevanje motivirana, drugače zdravljenje ne bo uspešno. Nekatere uporabnice menijo, da bi jih pro-ana skupnost pri zdravljenju podprla in jih ne bi poskušala odvrniti od okrevanja. Uporabnice se za uporabo pro-ana strani odločajo tudi zato, ker so strani anonimne in brezplačne, v nasprotju z visokimi cenami terapij.

Terapija navadno poteka $v$ živo, to pa lahko povzroča različne težave: obvezna navzočnost, strah pred nesprejetjem, socialna tesnoba, neučinkovito svetovanje (McCormack in Coulson, 2009, str. 9). Splet pomeni varen prostor brez predsodkov in stigmatizacije, prostor, kjer lahko ljudje, ki imajo različne težave, prosto in brezplačno posredujejo informacije in dobijo podporo na bolj anonimen način (Eichhorn, 2008, str. 67).

Polovica anketiranih še nikoli ni iskala pomoči glede zdravljenja, predvsem zaradi visokih cen zdravljenja in terapije ter lastne nepripravljenosti na zdravljenje.

In si ga ne morem privoščiti. (K7)

Tiste, ki pa so se odločile za zdravljenje, so se zatekale k terapiji, ki je nekaterim pomagala, nekaterim ne. Nekatere so pomoč iskale pri psihologih, v centru za duševno zdravje, skupini za samopomoč za osebe z motnjami hranjenja, pri srednješolskih svetovalcih (psihologu, socialni delavki), ki pa jih niso jemali resno. Večinoma so z izkušnjami nezadovoljne. Kot poglavitne razloge neučinkovitosti navajajo slabo pripravljenost terapevtov, da jih niso jemali resno in da so jih silili jesti. Menijo, da je terapija prek telefona ali spleta neučinkovita ter da je terapija lahko učinkovita le, če je terapevt sam imel motnjo hranjenja, saj tako uporabnice razume. Zdaj uporabnice namreč menijo, da jih terapevti in drugi strokovnjaki ne bodo razumeli. Velik del uporabnic pomoč išče na spletu, predvsem prek različnih pro-ana strani in podpornih aplikacij.

\section{Sklep}

Pro-ana strani imajo pomembno vlogo za tiste, ki trpijo zaradi motenj hranjenja. Kot socialne delavke moramo biti o teh straneh dobro obveščene. Pro-ana strani ponujajo uporabnicam možnost anonimnega pridobivanja informacij, vodenja in čustvene podpore (Branley in Covey, 2017, str. 2), zato si moramo socialne delavke prizadevati, da uporabnicam vse te stvari zagotovimo $\mathrm{v}$ resničnem življenju, na zdrav način. Tako ne bodo čutile potrebe zatekati se $\mathrm{k}$ pro-ana stranem. Da bi lahko uporabnicam pro-ana spletnih strani ustrezno pomagali, moramo strokovnjaki najprej razumeti, kaj pro-ana strani sploh so, 
kaj so njihove vloge in kaj so informacije, ki jih osebe z motnjami hranjenja prejemajo na teh straneh. Informacije o tem pa lahko prejmemo s sprotnimi usposabljanji in izobraževanji, saj se pro-ana strani in skupnosti nenehno posodabljajo in spreminjajo.

Zelo pomembno je, da socialne delavke osebam s težavami zaradi motenj hranjenja omogočimo varen prostor, $v$ katerem se ne bodo počutile obsojane, ampak bodo sprejete in slišane. Večina anketiranih uporabnic se namreč zaveda negativnih vplivov pro-ana strani in jih uporabljajo zgolj zaradi koristi, ki jih pro-ana strani zagotavljajo. Če uporabnice razkrijejo, da so strani uporabljale, ima socialna delavka lahko predstavo o tem, kakšne nasvete so si ogledale, in zato uporabnico vodi $\mathrm{k}$ nadaljnjemu pogovoru o netočnih informacijah, ki so jih prejele (Reali, 2015, str. 3). Z uporabnico se lahko pogovori o razlogih, zakaj je obiskovala pro-ana strani, in jo nato, na podlagi njenih odgovorov, usmeri k varnejšim, boljšim alternativam, npr. k skupini za samopomoč, če je uporabnica izrazila, da se je v svoji bolezni počutila osamljeno, pro-ana strani pa so ji dale občutek pripadnosti skupini; željo po pisanju bloga pa lahko nadomesti s pisanjem dnevnika. Skupaj z uporabnico raziskujemo njene potrebe. Usmerimo in spodbujamo jo k iskanju skupnosti, ki je usmerjena $\mathrm{v}$ zdravljenje in kjer se uporabnica lahko izpoveduje na varnejši način in ima prav tako občutek pripadnosti skupnosti.

Socialne delavke in drugi strokovnjaki bi morali bolje poznati pro-ana strani tudi zato, da se bodo uporabnice počutile bolj razumljene in jim bo lažje povedati, da take strani uporabljajo. Treba je povečati znanje o pro-ana skupnosti, poleg tega pa članicam te skupnosti, ki so prišle na terapijo, pomagati, da bi našle podporo tudi drugje. Več kot strokovnjaki vedo o tej tematiki, bolj lahko pomagajo svojim uporabnicam pri spoprijemanju s skušnjavo, da se po okrevanju vrnejo v pro-ana skupnost (Boniel-Nissim in Latzer, 2016, str. 19). Drugih koristi uporabe pro-ana strani v raziskavi nisva zaznali, saj je toliko več škodljivih elementov in se strinjava z uporabnicami, da pro-ana strani ni mogoče uporabiti kot sredstva pomoči za zdravljenje.

Predvsem je pomembno, da v obstoječih programih in storitvah, ki so namenjene osebam z motnjami hranjenja, socialne delavke še bolj uporabljamo sodobne koncepte socialnega dela, omogočamo varen prostor ter zagotavljamo podporo in pomoč na način soustvarjanja rešitev, ki bodo pomenile kakovostno okrevanje, da se bodo ljudje počutili sprejete in varne. To so namreč prav tisti vidiki, ki jih zdaj iščejo na pro-ana straneh.

\section{Viri}

Abbate, D. G., Gramaglia, C., Pierò, A., \& Fassino, S. (2006). Eating disorders and the Internet: cure and curse. Eating and Weight Disorders, 11(2), 68-71. Pridobljeno 30. 1. $2020 \mathrm{~s}$ https://www.ncbi.nlm.nih.gov/pubmed/16809973

Bine, A. S. (2013). Social media is redefining 'depression'. Pridobljeno 30. 1. 2020 s https:// www.theatlantic.com/health/archive/2013/10/social-media-is-redefining-depression/280818/

Bond, E. (2012). Virtually anorexic - where's the harm? A research study on the risks of pro-anorexia websites. London: Childnet International. 
Boniel-Nissim, M., \& Latzer, Y. (2016). The characteristics of Pro-Ana community. Pridobljeno 20. 1. $2020 \mathrm{~s}$ http://www.mbn-psychonet.com/AllSites/1799/Assets/14.pdf

Borzekowski, D. L., Schenk, S., Wilson, J. L., \& Peebles, R. (2010). e-Ana and e-Mia: a content analysis of pro-eating disorder Web sites. American Journal of Public Health, 100(8), 1526-1534. Pridobljeno 1. 1. 2020 s https://www.ncbi.nlm.nih.gov/pmc/articles/ PMC2901299/

Branley, D. B., \& Covey, J. (2017). Pro-ana versus Pro-recovery: a content analytic comparison of social media users' communication about eating disorders on Twitter and Tumblr. Frontiers in Psychology, 8(1356), 1-8. Pridobljeno 2. 2. 2020 s https://www.ncbi.nlm.nih. gov/pmc/articles/PMC5554530/

Bronstein, J. (2013). Personal blogs as online presences on the internet: exploring self-presentation and self-disclosure in blogging. Aslib Proceedings, 65(2), 161-181. Pridobljeno 12. 1. 2020 s https://www.researchgate.net/publication/263143004_Personal_blogs_as_online_presences_on_the_internet_Exploring_self-presentation_and_self-disclosure_in_blogging

Ciotti, G. (2016). The psychological benefits of writing. [Blog]. Pridobljeno 21. 1. $2020 \mathrm{~s}$ https://www.helpscout.com/blog/benefits-of-writing/

Conger, K. (2006). Two studies offer new insights into eating disorders. Pridobljeno 27. 9. 2019 s https://news.stanford.edu/news/2006/december6/med-eating-120606.html

Černe, G. (2020). Vloga pro-ana spletnih strani pri težavah z motnjami hranjenja. (diplomsko delo). Ljubljana: Fakulteta za socialno delo.

De Shazer, S. (1985). Keys to solution in brief therapy. New York: W. W. Norton.

Eichhorn, K. C. (2008). Soliciting and providing social support over the Internet: investigation of online eating disorder support groups. Journal of Computer-Mediated Communication, 14(1), 67-78. Pridobljeno 28. 1. 2020 s https://academic.oup.com/jcmc/ article/14/1/67/4582965

Happel Krautbauer, K. (2016). A grounded theory analysis of the functions of proana social media accounts (magistrsko delo). Pridobljeno 26. 9. $2019 \mathrm{~s} \mathrm{https://pdfs.semanticscho-}$ lar.org/2a30/4c754988394b1a3d8fa7e6254983831d6e32.pdf

Hekman, E. (2016). Pro-recovery: an exploration of online communities and support for eating disorders on Instagram (magistrsko delo). Pridobljeno 20. 1. 2020 s https://scripties. uba.uva.nl/scriptie/620207

Ko, H.-C., \& Pu, H.-J. (2011). Understanding the impact of bloggers'self-disclosure on resilience. Paper presented at the 5th International Conference on Ubiquitous Information Management and Communication, Seoul, Korea.

McCormack, A., \& Coulson, N. S. (2009). Individuals with eating disorders and the use of online support groups as a form of social support. Psychosocial Research on Cyberspace, 3(2), 12-19. Pridobljeno 29. 1. 2020 s https://cyberpsychology.eu/article/ view/4228/3271

Mesec, B. (1997). Metodologija raziskovanja v socialnem delu I: načrtovanje raziskave (študijsko gradivo za interno uporabo). Ljubljana: Fakulteta za socialno delo.

Miura, A., \& Yamashita, K. (2007). Psychological and social influence on blog writing: an online survey of blog authors in Japan. Journal of Computer-Mediated Communication, 12(4), 1452-1471. Pridobljeno 14. 1. 2020 s https://www.researchgate.net/publication/220438174_Psychological_and_Social_Influences_on_Blog_Writing_An_Online_Survey_of_Blog_Authors_in_Japan

Mulveen, R., \& Hepworth, J. (2006). An interpretive phenomenological analysis of participation in a pro-anorexia internet site and its relationship with disordered eating. Journal of Health Psychology, 11(2), 283-296. Pridobljeno 13. 1. 2020 s https://www.ncbi.nlm.nih. gov/pubmed/16464925

Patel, R., Chang, T., Greysen, S. R., \& Chopra, V. (2015). Social media use in chronic disease: a systematic review and novel taxonomy. The American Journal of Medicine, 128(12), 1335-1350. Pridobljeno 28. 1. 2020 s https://www.ncbi.nlm.nih.gov/pubmed/26159633

Pettersen, H. H., Rørvik, S. A., \& Wanvik, H. (2011). Exploring the experience of having an 
eating disorder and blogging about the illness: an interpretative phenomenological analysis. Bergen: Faculty of Psychology, University of Bergen.

Reali, E. C. (2015). Advice giving in online eating disorder forums: what clinical social workers need to know (magistrsko delo). Pridobljeno 10. 1. $2020 \mathrm{~s} \mathrm{https://scholarworks.smith.}$ edu/theses/651/

Rich, E. (2006). Anorexic dis(connection): managing anorexia as an illness and an identity. Sociology of Health \& Illness, 28(3), 284-305. Pridobljeno 12. 1. 2020 s https://onlinelibrary.wiley.com/doi/full/10.1111/j.1467-9566.2006.00493.x

Richards, J. M., Beal, W. E., Seagal, J. D., \& Pennebaker, J. W. (2000). Effects of disclosure of traumatic events on illness behavior among psychiatric prison inmates. Journal of Abnormal Psychology, 109(1), 156-160. Pridobljeno 16. 1. 2020 s https://psycnet.apa.org/ record/2000-13847-019

Schmidt, U., Bone, G., Hems, S., Lessem, J., \& Treasure, J. (2002). Structured therapeutic writing tasks as an adjunct to treatment in eating disorders. European Eating Disorders Review, 10(5), 299-315. Pridobljeno 16. 1. 2020 s https://www.researchgate.net/publication/227814826_Structured_therapeutic_writing_as_an_adjunct_to_treatment_in_eating_disorders

Schroeder P. A. (2010). Adolescent girls in recovery for eating disorders: exploring past pro-anorexia internet community experiences. Alhambra, CA: Alliant International University.

Skårderud, F. (2003). Sh@me in cyberspace. Relationships without faces: the e-media and eating disorders. European Eating Disorders Review, 11(3), 5-169. Pridobljeno 19. 1. 2020 s http://in3.uoc.edu/opencms_in3/export/sites/in3/webs/grups_de_recerca/psinet/_resources/documents/Skarderud.pdf

Strife, S., \& Rickard, K. (2011). The conceptualization of anorexia: the pro-ana perspective. Affilia: Journal of Women and Social Work, 26(2), 213-217. Pridobljeno 12. 1. $2020 \mathrm{~s}$ https://journals.sagepub.com/doi/10.1177/0886109911405592

Tierney, S. (2006). The dangers and draw of online communication: pro-anorexia websites and their implications for users, practitioners, and researchers. Eating Disorders, 14(3), 181-190. Pridobljeno 18. 1. 2020 s https://www.ncbi.nlm.nih.gov/pubmed/16807213

Tozzi, F., Sullivan, P. F., Fear, J. L., McKenzie, J., \& Bulik, C. M. (2003). Causes and recovery in anorexia nervosa: the patient's perspective. International Journal of Eating Disorders, 33(2), 143-54. Pridobljeno 20. 1. 2020 s http://citeseerx.ist.psu.edu/viewdoc/download?doi=10.1. 1.413.8115\&rep=rep1\&type=pdf

Van Pelt, J. (2009). Eating disorders on the Web - the Pro-Ana/Pro-Mia movement. Social Work Today, 9(5), 20. Pridobljeno 7. 10. 2020 s https://www.socialworktoday.com/ archive/092109p20.shtml

Winzelberg, A. (1997). The analysis of an electronic support group for individuals with eating disorders. Computers in Human Behavior, 13(3), 393-407. Pridobljeno 27. 1. $2020 \mathrm{~s}$ https://bit.ly/3jRa0c9 
